\title{
Association of Plasma Level of Lithium with Clinical Effect in Bipolar Disorder at a Tertiary Center in Eastern Nepal
}

\author{
Nepal S1, Sarraf DP², Baral DD, Mishra SK ${ }^{1}$, Chaudhari RK ${ }^{4}$, Sapkota $\mathrm{N}^{5}$ \\ 1. Assistant Professor, Department of Psychiatry, B.P. Koirala Institute of Health Sciences, Dharan, \\ Nepal 2. Associate Professor, Department of Clinical Pharmacology and Therapeutics, B.P. Koirala \\ Institute of Health Sciences, Dharan, Nepal 3. Assistant Professor, School of Public Health and \\ Community Medicine, B.P. Koirala Institute of Health Sciences, Dharan, Nepal 4. Associate Professor, \\ Department of Biochemistry, B.P. Koirala Institute of Health Sciences, Dharan, Nepal 5. Additional \\ Professor, Department of Psychiatry, B.P. Koirala Institute of Health Sciences, Dharan, Nepal
}

E-mail *Corresponding author: surajnepal51@gmail.com

\begin{abstract}
Introduction: Lithium is widely used as the gold standard for the treatment of acute and maintenance treatment of Bipolar Affective Disorder (BPAD). Its therapeutic benefits are restricted by several adverse drug reactions (ADR). Therefore, it is necessary to measure its serum concentration for optimal dosing and clinical response and to minimize toxicity. The objectives of the study were to correlate dose of Lithium with its serum concentration and serum concentration of lithium with clinical effect.
\end{abstract}

Material And Method: A cross sectional study was conducted in 213 patients presenting to psychiatric OPD, diagnosed with BPAD and taking Lithium monotherapy at least for 3 months. Data collection was done from 15th December 2018 to14th December 2019. Sociodemographic profile and relevant laboratory investigations were recorded on a self-designed proforma. Young Mania Rating Scale and Hamilton Rating Scale for Depression were applied for objective assessment of remission. Chi square test was used to correlate categorical data and ANOVA test was used for continuous data using SPSS at P-value of 0.05 .

Results: Majority of patients were male (51.6\%), married (62.4\%), Hindu (86.9\%) and in remission phase (92\%). Dose of lithium was 300-1200 mg/day; serum concentration was 0.26 to $1.51 \mathrm{mmol} / \mathrm{L}$, was in therapeutic range in majority of the patients $(82.6 \%)$ and was positively correlated with the dose of lithium (P-value <0.0001).

Conclusion: Lithium is very effective for maintenance therapy in BPAD with wide variation in dose and serum concentration. The dose of lithium should be guided both on the basis of clinical assessment and serum concentration.

Keywords: Bipolar affective disorder, Lithium, Serum concentration

\section{INTRODUCTION}

Bipolar affective disorder (BPAD) is characterized by episodes of hypomania, mania and mixed episodes with or without depressive episodes, with inter-episodic recovery. Lithium is used as the gold standard for the treatment of acute episodes and maintenance treatment of BPAD. ${ }^{1,2}$ It has a narrow therapeutic range and therefore both its efficacy and toxicity are dosedependent and therefore the margin between toxic, therapeutic and sub-therapeutic serum levels are liable to be crossed. ${ }^{3}$ A number of factors like genetics, age, gender, ethnicity, nutritional status, smoking, comorbid disease and drug interactions affect metabolism and clearance of lithium. ${ }^{4-6}$

The optimal serum level of lithium for the prevention and treatment of BAPD is still unclear.7It has been observed that lithium frequently produces toxic effects in Nepalese patients at usual recommended dose of lithium. Most of Nepalese patients have toxic effects even at serum concentration of 0.6 to 1.2 $\mathrm{mmol} / \mathrm{L}$ and at this dose there are minimal toxic effect in western patients. ${ }^{8}$ There is paucity of reports on relationship between concentration of lithium and its clinical response in Nepalese population. Evidence to support the efficacy of 
lithium at lower serum concentrations in Nepalese patients is also lacking.Therefore, this study wasconducted to correlate dose of Lithium with serum concentration of lithium and the serum concentration of lithium with clinical effect.

\section{MATERIAL AND METHOD}

A cross-sectional prospective study was conducted among patients having BPAD at Outpatient department of Psychiatry, B.P.Koirala Institute of Health Sciences, Dharan, Nepal from 15 th December 2018 to $14^{\text {th }}$ December 2019. Patients diagnosed with BPAD and taking lithium as monotherapy for at least 3 months were enrolled. Pregnant patients, taking other psychotropic drugs like Benzodiazepines, antipsychotics, antidepressants and antianxiety drugs, patients not giving consent were excluded.

A self-designed proforma was used to collect sociodemographic profile(name, age, sex, marital status, socioeconomic status, educational status), weight, height, co-morbid conditions, laboratory investigations (Urine RE/ME, urea/creatinine, Thyroid function test and ECG), drugs prescribed (name, dose, duration) and serum concentration of lithium. Blood sample was taken 12 hours after evening dose of lithium and its concentration was measured through Colorimetric test (Roche/Hitachi Cobas c 501 analyzer, Roche Diagnostics, USA). The Young Mania Rating Scale (YMRS) isa validated and reliable tool to assess bipolar manic symptoms. ${ }^{9}$ It has 11-item. Thepatients having YMRS score zero were designated as being in remission phase.Hamilton Depression Rating Scale (HDRS) is a validated and reliable tool to assess the depression in BPAD. It has 17item. ${ }^{10}$ Thepatients having HDRS score 7 or less were designated as being in remission phase.

The objectives of the study were explained to the eligible patients at the time of consultation in psychiatry outpatient department and written consent was taken. The relevant data were collected directly in the proforma by reviewing the health card of the patients and by face-toface interview.The questionnaire were first prepared in English language and then translated in Nepali language by a separate translator and it was back-translated to English by an independent translator. The Nepali version was used to collect the relevant data. The questionnaire was pilot tested in 22 patients to validate it and those patients were not included in the analysis. The study was approved by Institutional Review Committee (IRC/1263/018), BPKIHS, Dharan, Nepal.

The data were entered into MS-Excel 2007. Descriptive statistics mean, frequency, percentage and $\mathrm{SD}$ were calculated.Basal metabolic index $\left(\mathrm{Kg} / \mathrm{m}^{2}\right)$ was calculated and categorized into underweight, normal weight, overweight and obese as per international guideline. ${ }^{26}$ Serum concentration of lithium was also categorized as "Below therapeutic level $(<0.6 \mathrm{mmol} / \mathrm{L})$ ", "Therapeutic level (0.6$1.2 \mathrm{mmol} / \mathrm{L})$ " and "Above therapeutic level $(>1.2 \mathrm{mmol} / \mathrm{L}) "{ }^{11}$ ANOVA test, Student $\mathrm{t}$ test, and Spearman's rho correlation test was used for analyzing non-categorical data and Chi-square test for categorical data. P-value $<0.05$ was considered as statistically significant. All statistical calculations were performed using SPSS version 11.0 (Chicago, USA).

\section{RESULT}

Out of 213 patients, majority were male (51.6\%), married (62.4\%), Hindu (86.9\%), Aryan (80.3\%) and in $3^{\text {rd }}$ to $4^{\text {th }}$ decade of their life (63.4\%). Most of the patients $(47.4 \%)$ had completed secondary level of education.Sixty nine $(32.4 \%)$ patients were substance user (Table 1). Eight patients $(3.8 \%)$ had comorbidities and hypertension (50\%) was the commonest comorbidity followed by diabetes mellitus (25\%) and mental retardation (25\%).Urine RE/ME, Renal function test (serum urea and creatinine) and ECG were within normal limits in all patients.

Table 2 represents the descriptive data of the patients. Mean age of the patients was $32.06 \pm 10.80$ years. Mean duration of lithium (Li) therapy was $27.78 \pm 16.24$ months (Table 2 ).

More than one third of the patients (37.1\%) were taking lithium for 13-24 months followed by 612 months (21.1\%) (Figure 1).

Most of the patients (42.3\%) had normal weight and $30.5 \%$ were overweight (Figure 2)

Age had negative correlation with serum level of lithium; however it was statistically not significant (P-value $>0.05)$. Similarly Serum level of lithium had positive correlation with BMI, duration of lithium therapy and dose of the lithium; however it was statistically 
significantonly with the dose ( $P$-value $>0.05)$. (Table 3).

Table 1: Socio demographic characteristics of the patients $(\mathrm{n}=\mathbf{2 1 3})$

\begin{tabular}{|c|c|c|c|}
\hline Variables & Categories & $\begin{array}{l}\text { Number } \\
\text { of } \\
\text { patients }\end{array}$ & Percentage \\
\hline \multirow[t]{2}{*}{ Gender } & Male & 110 & 51.6 \\
\hline & Female & 103 & 48.4 \\
\hline \multirow{5}{*}{$\begin{array}{l}\text { Age category } \\
\text { (years) }\end{array}$} & $12-20$ & 32 & 15 \\
\hline & $21-30$ & 76 & 35.7 \\
\hline & $31-40$ & 59 & 27.7 \\
\hline & $41-50$ & 34 & 16 \\
\hline & $>60$ & 12 & 5.6 \\
\hline \multirow{4}{*}{ Marital status } & Married & 133 & 62.4 \\
\hline & Unmarried & 70 & 32.9 \\
\hline & Divorced & 7 & 3.3 \\
\hline & Widow & 3 & 1.4 \\
\hline \multirow{3}{*}{$\begin{array}{l}\text { Socioeconomic } \\
\text { status }\end{array}$} & Low & 96 & 45.1 \\
\hline & $\begin{array}{l}\text { Low } \\
\text { middle }\end{array}$ & 62 & 29.1 \\
\hline & Middle & 55 & 25.8 \\
\hline \multirow{5}{*}{$\begin{array}{l}\text { Educational } \\
\text { level }\end{array}$} & Illiterate & 19 & 8.9 \\
\hline & Primary & 45 & 21.1 \\
\hline & Secondary & 101 & 47.4 \\
\hline & $\begin{array}{l}\text { Higher } \\
\text { secondary }\end{array}$ & 34 & 16 \\
\hline & $\begin{array}{l}\text { Bachelor } \\
\text { and above }\end{array}$ & 14 & 6.6 \\
\hline \multirow{5}{*}{ Religion } & Hindu & 185 & 86.9 \\
\hline & Christian & 10 & 4.7 \\
\hline & Kirat & 8 & 3.8 \\
\hline & Muslim & 7 & 3.3 \\
\hline & Buddhist & 3 & 1.4 \\
\hline \multirow{2}{*}{ Race } & Aryan & 171 & 80.3 \\
\hline & Mongolian & 42 & 19.7 \\
\hline \multirow{2}{*}{$\begin{array}{l}\text { Substance } \\
\text { user }\end{array}$} & Yes & 69 & 32.4 \\
\hline & No & 144 & 67.6 \\
\hline
\end{tabular}

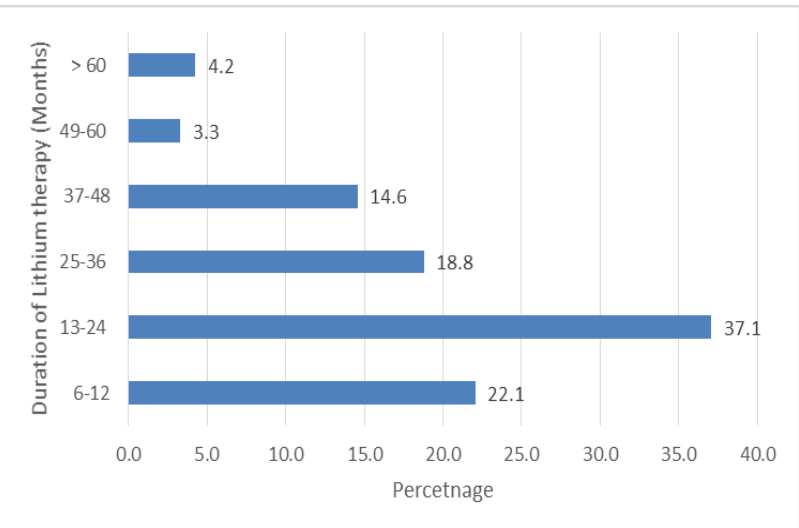

Figure 1: Duration of Lithium therapy in years $\underline{(n=213)}$

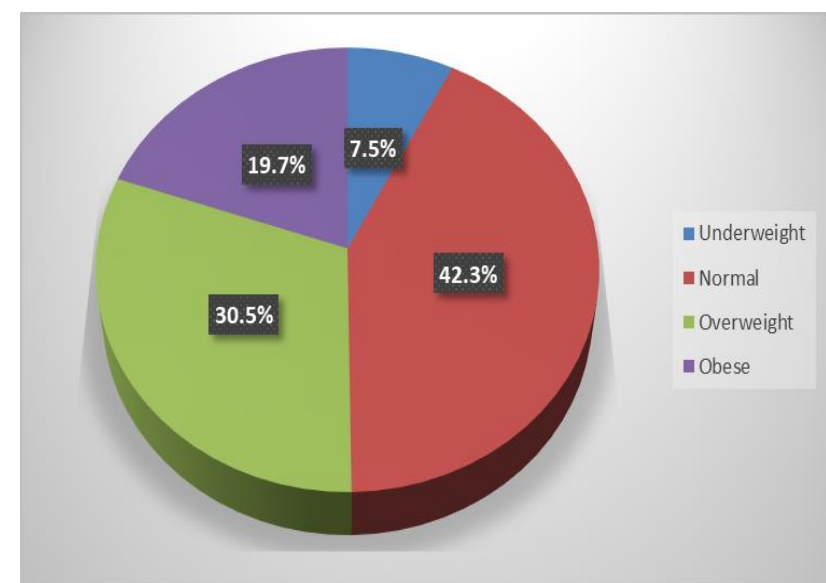

Figure 2: Category of BMI $(\mathrm{kg} / \mathrm{m} 2)$ of the patients $(\mathrm{n}=213)$

Table 2: Descriptive statistics of the patients $(n=213)$

\begin{tabular}{|l|c|c|c|c|c|c|}
\hline \multicolumn{1}{|c|}{ Variables } & Mean & SD & Median & Mode & Minimum & Maximum \\
\hline Age in years & 23.06 & 10.805 & 30 & 28 & 12 & 72 \\
\hline Body Mass Index in Kg/m ${ }^{2}$ & 22.65 & 2.99 & 23 & 21 & 16 & 34.4 \\
\hline $\begin{array}{l}\text { Duration on lithium therapy } \\
\text { in months }\end{array}$ & 27.78 & 16.244 & 23 & 21 & 6 & 96 \\
\hline Dose of lithium in mg/day & 891.9 & 152.69 & 900 & 900 & 300 & 1200 \\
\hline $\begin{array}{l}\text { Serum level of lithium } \\
\text { inmmol/L }\end{array}$ & 0.800 & 0.211 & 0.800 & 0.800 & 0.26 & 1.51 \\
\hline
\end{tabular}


Table 3: Correlation of Serum lithium level with age, BMI, duration of lithium therapy and dose $(\mathrm{n}=\mathbf{2 1 3})$

\begin{tabular}{|l|c|c|}
\hline \multirow{2}{*}{ Variable } & \multicolumn{2}{|c|}{ Serum level of Lithium } \\
\cline { 2 - 3 } & $\begin{array}{l}\text { Pearson's } \\
\text { coefficient (r) }\end{array}$ & P-value \\
\hline Age & -0.08 & 0.242 \\
\hline BMI of & 0.024 & 0.732 \\
\hline $\begin{array}{l}\text { Duration } \\
\text { lithium therapy }\end{array}$ & 0.085 & $0.218^{\$}$ \\
\hline $\begin{array}{l}\text { Dose of the } \\
\text { lithium }\end{array}$ & 0.469 & $<0.001^{*}$ \\
\hline
\end{tabular}

\$Spearman's rho correlation test

${ }^{*}$ Statistically significant (Pearson Correlation test)

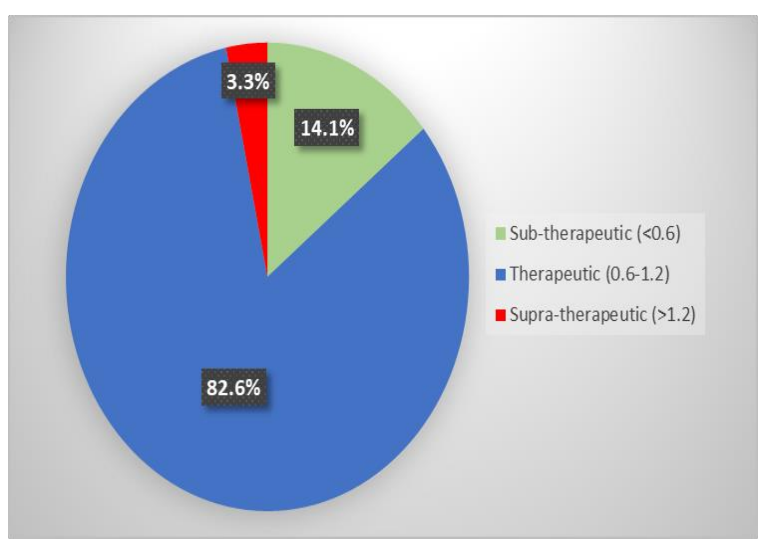

Figure 3: Category of serum concentration (mmol/L) of Lithium in the patients $(n=213)$

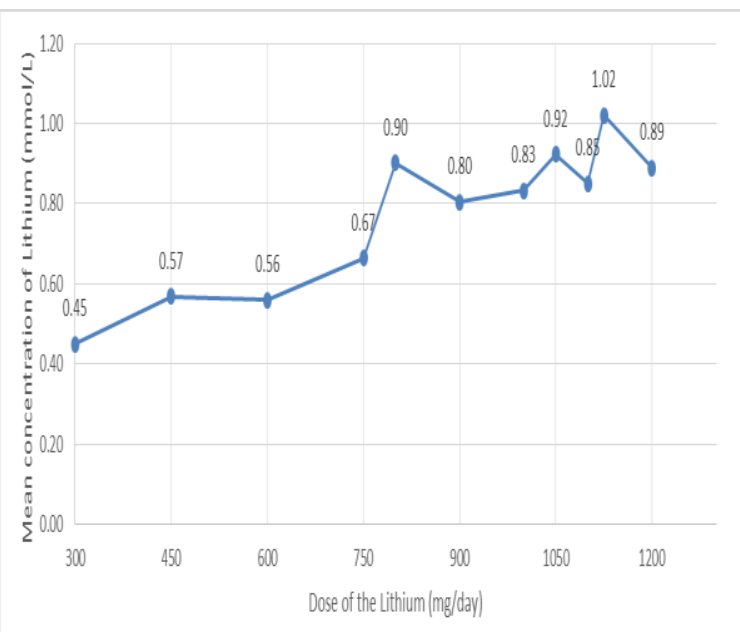

Figure 4: Line diagram of mean serum concentration of Lithium and its dose per day

Table 4: Serum level of Lithium at each dose $(n=213)$

\begin{tabular}{|c|c|c|c|c|c|c|}
\hline $\begin{array}{l}\text { Lithium } \\
\text { dose } \\
(\mathrm{mg} / \text { day) }\end{array}$ & $\begin{array}{l}\text { Number } \\
\text { of } \\
\text { Patients }\end{array}$ & $\begin{array}{l}\text { Serum } \\
\text { concentration } \\
\text { of Lithium } \\
(\mathrm{mmol} / \mathrm{L})\end{array}$ & $\begin{array}{l}\text { Mean } \pm \text { SD } \\
(\mathrm{mmol} / \mathrm{L})\end{array}$ & $\begin{array}{l}\text { Below } \\
\text { therapeutic } \\
\text { range } \\
(<0.6 \mathrm{mmol} / \mathrm{L})\end{array}$ & $\begin{array}{l}\text { Therapeutic range } \\
(0.6-1.2 \mathrm{mmol} / \mathrm{L})\end{array}$ & $\begin{array}{l}\text { Above } \\
\text { therapeutic } \\
\text { range } \\
(>1.2 \mathrm{mmol} / \mathrm{L})\end{array}$ \\
\hline 300 & 1 & 0.41 & - & 1 & 0 & 0 \\
\hline 450 & 8 & $0.45-0.6$ & $0.568 \pm 0.053$ & 3 & 5 & 0 \\
\hline 600 & 14 & $0.26-0.9$ & $0.561 \pm 0.176$ & 5 & 9 & 0 \\
\hline 750 & 6 & $0.5-0.7$ & $0.665 \pm 0.125$ & 2 & 4 & 0 \\
\hline 800 & 9 & $0.65-1.0$ & $0.801 \pm 0.120$ & 0 & 104 & 4 \\
\hline 900 & 123 & $0.31-1.51$ & $0.803 \pm 0.197$ & 15 & 2 & 0 \\
\hline 1000 & 4 & $0.55-1.2$ & $0.832 \pm 0.319$ & 2 & 35 & 3 \\
\hline 1050 & 40 & $0.54-1.4$ & $0.923 \pm 0.182$ & 2 & 1 & 0 \\
\hline 1100 & 1 & 0.85 & - & 0 & 3 & 0 \\
\hline 1125 & 3 & $0.75-1.18$ & $1.02 \pm 0.235$ & 0 & 4 & 0 \\
\hline 1200 & 4 & $0.67-1.1$ & $0.890 \pm 0.195$ & 0 & & 0 \\
\hline
\end{tabular}


Table 5: Correlation of Clinico-demographic variables with serum lithium concentration

\begin{tabular}{|c|c|c|c|}
\hline \multicolumn{2}{|c|}{ Variables } & \multirow{3}{*}{$\begin{array}{l}\begin{array}{l}\text { Mean serum } \\
\text { concentratio } \\
n \text { of lithium } \pm \\
\text { SD }\end{array} \\
0.816 \pm 0.208 \\
0.784 \pm 0.214\end{array}$} & \multirow{3}{*}{$\begin{array}{l}\begin{array}{l}\text { P- } \\
\text { valu } \\
\text { e }\end{array} \\
0.261\end{array}$} \\
\hline \multirow[t]{2}{*}{ Gender } & Male & & \\
\hline & Female & & \\
\hline \multirow[t]{4}{*}{ Marital status } & Married & $0.804 \pm 0.196$ & \multirow{4}{*}{0.510} \\
\hline & Unmarried & $0.806 \pm 0.228$ & \\
\hline & Divorced & $0.834 \pm 0.256$ & \\
\hline & Single & $0.466 \pm 0.162$ & \\
\hline \multirow{5}{*}{$\begin{array}{l}\text { Age category } \\
\text { (years) }\end{array}$} & $12-20$ & $0.772 \pm 0.221$ & \multirow{5}{*}{0.299} \\
\hline & $21-30$ & $0.824 \pm 0.199$ & \\
\hline & $31-40$ & $0.806 \pm 0.211$ & \\
\hline & $41-50$ & $0.804 \pm 0.234$ & \\
\hline & $>60$ & $0.690 \pm 0.183$ & \\
\hline \multirow[t]{5}{*}{ Religion } & Hindu & $0.795 \pm 0.211$ & \multirow{5}{*}{0.461} \\
\hline & Muslim & $0.875 \pm 0.252$ & \\
\hline & Buddhist & $0.740 \pm 0.165$ & \\
\hline & Christian & $0.773 \pm 0.250$ & \\
\hline & Kirat & $0.912 \pm 0.121$ & \\
\hline \multirow[t]{2}{*}{ Race } & Aryan & $0.796 \pm 0.211$ & \multirow{2}{*}{0.581} \\
\hline & Mongolian & $0.817 \pm 0.213$ & \\
\hline \multirow{3}{*}{$\begin{array}{l}\text { Socioeconomi } \\
\text { c status }\end{array}$} & Low & $0.813 \pm 0.199$ & \multirow{3}{*}{0.275} \\
\hline & Low middle & $0.764 \pm 0.202$ & \\
\hline & Middle & $0.819 \pm 0.238$ & \\
\hline \multirow{5}{*}{$\begin{array}{l}\text { Educational } \\
\text { level }\end{array}$} & Illiterate & $0.746 \pm 0.220$ & \multirow{5}{*}{0.358} \\
\hline & Primary & $0.783 \pm 0.205$ & \\
\hline & Secondary & $0.795 \pm 0.203$ & \\
\hline & $\begin{array}{l}\text { Higher } \\
\text { secondary }\end{array}$ & $0.859 \pm 0.166$ & \\
\hline & $\begin{array}{l}\text { Bachelor } \\
\text { and above }\end{array}$ & $0.826 \pm 0.338$ & \\
\hline \multirow[t]{2}{*}{ Comorbidities } & Yes & $0.741 \pm 0.291$ & \multirow{2}{*}{0.417} \\
\hline & No & $0.803 \pm 0.208$ & \\
\hline \multirow{2}{*}{$\begin{array}{l}\text { Taking other } \\
\text { drugs }\end{array}$} & Yes & $0.710 \pm 0.269$ & \multirow{2}{*}{0.454} \\
\hline & No & $0.802 \pm 0.211$ & \\
\hline \multirow{2}{*}{$\begin{array}{l}\text { Substance } \\
\text { user }\end{array}$} & Yes & $0.775 \pm 0.203$ & \multirow{2}{*}{0.220} \\
\hline & No & $0.813 \pm 0.214$ & \\
\hline \multirow{6}{*}{$\begin{array}{l}\text { Duration of } \\
\text { lithium } \\
\text { therapy } \\
\text { (months) }\end{array}$} & $6-12$ & $0.778 \pm 0.228$ & \multirow{6}{*}{0.771} \\
\hline & $13-24$ & $0.789 \pm 0.200$ & \\
\hline & $25-36$ & $0.820 \pm 0.186$ & \\
\hline & $37-48$ & $0.845 \pm 0.238$ & \\
\hline & $49-60$ & $0.778 \pm 0.221$ & \\
\hline & $>60$ & $0.796 \pm 0.241$ & \\
\hline \multirow[t]{4}{*}{ BMI } & $\begin{array}{l}\text { Underweigh } \\
\mathrm{t}\end{array}$ & $0.775 \pm 0.200$ & \multirow{4}{*}{0.889} \\
\hline & $\begin{array}{l}\text { Normal } \\
\text { weight }\end{array}$ & $0.799 \pm 0.215$ & \\
\hline & Overweight & $0.815 \pm 0.226$ & \\
\hline & Obese & $0.792 \pm 0.186$ & \\
\hline
\end{tabular}

Serum concentration of lithium was high in those patients who were male, divorced, aged 21-30 years, Kirat, Mongolian, overweight, substance user, having comorbidities, taking other drugs, completed higher secondary education, middle socioeconomic status and duration of therapy having 37-48 months; however, it was statistically not significant (Pvalue $>0.005$ ) (Table 5).

YMRS and HDRS score showed that out of 213 patients, 196 patients (92\%) were in remission phase and it was observed in all category of serum concentration (Therapeutic, Below and Above therapeutic) of lithium; however, it was statistically not significant (P-value $>0.005)$ (Table 6).

Table 6: Correlation of serum concentration of lithium with remission

\begin{tabular}{|l|c|c|c|}
\hline Serum $\begin{array}{l}|c| \\
\text { concentration of } \\
\text { Lithium }\end{array}$ & \multicolumn{2}{|c|}{ Remission } & \multirow{2}{*}{ P-value } \\
\cline { 2 - 3 } & & No & \\
\hline Below therapeutic & 28 & 2 & \multirow{2}{*}{0.688} \\
\hline Therapeutic & 161 & 15 & \\
\hline Above therapeutic & 7 & 0 & \\
\hline
\end{tabular}

\section{DISCUSSION:}

Our study provides statistical evidence of positive relationship between the prescribed dose and serum concentration of lithium and similar results had been demonstrated by Bhandari et al and Lamichhane et al.12,13 It is better to follow the guidelines and have therapeutic drug monitoring of lithium before increasing its dose; otherwise there may be attainment of toxic level of lithium in some patients. Male to female ratio was almost equal to 1 in our study. Higher number of male had BPAD in other study. ${ }^{12,14}$ However, most studies report an almost equal gender ratio in the prevalence of BPAD. ${ }^{15}$ Majority of the patients were in $3^{\text {rd }}$ and $4^{\text {th }}$ decade of their life with mean age of $32.06 \pm 10.80$ years. A higher mean age $(37.46 \pm 1.54)$ was reported in other studies. ${ }^{3,14}$ BPAD is a chronic mental illness with the peak age of onset between 20 and 40 years. ${ }^{16}$ These group of patients may have more stressful life as compared to others.Most of the patient had low SES in our study. Similar distribution of BPAD was seen in other studies. ${ }^{17}$ Tsuchiya et al has suggested that BPAD is more common in low income, unemployed and unmarried groups of people. ${ }^{18}$ Nearly one third of the patients were substance 
user. Substance abuse is particularly common in BPAD and its co-occurrence often leads to a more pernicious and difficult to treat course of illness. ${ }^{19}$ Mean BMI was $22.65 \mathrm{Kg} / \mathrm{m}^{2}$ in our study. In contrast to this, mean BMI was higher $\left(24.96 \mathrm{Kg} / \mathrm{m}^{2}\right)$ in a study by Lamichhane $\mathrm{N}$ et al. ${ }^{12}$ Dose of lithium ranged from 300 to 1200 $\mathrm{mg} /$ day and mean dose was $891.9 \mathrm{mg}$ and similar results had been reported in other study. ${ }^{12}$ In contrast to this, $600 \mathrm{mg}$ was the minimum dose of lithium in an Indian study. ${ }^{13}$ Minimum effective serum level of lithium was $0.26 \mathrm{mmol} / \mathrm{L}$ in our study. In contrast to this, minimum effective serum concentration of lithium was $0.16 \mathrm{mmol} / \mathrm{L}$ in a study by Lamichhane $\mathrm{N}$ et $\mathrm{al}^{12} \mathrm{~A}$ higher minimal efficacious serum level $(0.4$ and $0.39 \mathrm{mmol} / \mathrm{L})$ was reported in other studies.,713 The guidelines has suggested that serum level of $0.6-0.8$ $\mathrm{mmol} / \mathrm{L}$ is optimum for prophylaxis of BPAD which is higher than our findings. ${ }^{2}$ Most clinicians advocate a serum concentration of 0.8 $1.2 \mathrm{mEq} / \mathrm{L}$ during initial treatment of acute mania. ${ }^{20}$ Some patients may require serum lithium concentrations outside the usual ranges. For instance, elderly patients may require lower levels.

Mean serum concentration was $0.800 \pm 0.211$ $\mathrm{mmol} /$ Lin our study. Lamichhane et al had reported a lower mean serum level of lithium $(0.596 \pm 0.211 \mathrm{mmol} / \mathrm{L})$ in their study. ${ }^{12}$ Interindividual variation in pharmacokinetics and pharmacodynamics, as well as such external factors as diet and concomitant medications can affect serum lithium levels. ${ }^{21}$ Therefore it is better to choose the dose of lithium based on individual patients' characteristics in BPAD.

Majority of the patients had serum concentration of lithium in therapeutic level in our study and similar results had been reported by Sharma et al.22Serum therapeutic level was out of therapeutic range in $17.4 \%$ patients in our study and was similar to the report of Sharma et al. ${ }^{22}$ In contrast to this, it was out of therapeutic range in $44.6 \%$ patients in a study conducted in Thailand. ${ }^{23}$ One third of the patients had subtherapeutic level of lithium in a study by Marcus et al. ${ }^{24}$ Remission was seen in all category of serum concentration (Therapeutic, Below/Above therapeutic) of lithium in our study. Randomized clinical trials are needed to establish therapeutic serum level of lithium in Nepalese population.

Lithium monotherapy was effective in BPAD in all age group in our study. It is beneficial to use the lowest possible dose of lithium to prevent immediate and long-term ADR in a patient who is on long-term maintenance therapy. The same brand of lithium should always be prescribed in BPAD as different preparations of lithium vary in bioavailability. Care should be taken, including additional monitoring, of changing between brands. Potential organ toxicity due to chronic lithium therapy requires more vigilance. Limitations:Our study has some limitations. Calcium level was not checked in spite of hyperthyroidism being an ADR of lithium therapy. Effect of different brands of lithium on its serum concentration were not evaluated. Patient compliance to the prescribed lithium could not be assessed.

\section{CONCLUSION:}

Within the limitation of our study, the study findings showed that the lithium is very effective for maintenance therapy in BPAD at various doses. There is wide variation in its maintenance dose and serum concentration. Dose of the lithium should be guided both on the basis of clinical assessment and serum concentration. The serum concentration of lithium is inversely related with age and hence its maintenance dose should be less in young and elderly patients as compared to middle aged patients.

ACKNOWLEDGEMENT: We would like to thank the patients who participated in the study.

FUNDING: None

\section{CONFLICT OF INTEREST: None}

\section{REFERENCES:}

1. Nolen W. More robust evidence for the efficacy of lithium in the long-term treatment of bipolar disorder: should lithium (again) be recommended as the single preferred first-line treatment? Int J BipolDisord. 2015;31(3):1.

2. Shah N, Grover S, Rao GP. Clinical Practice Guidelines for Management of Bipolar Disorder. Indian J Psychiatry. 2017;59(Suppl 1):S51-S66.

3. Grandjean EM, Aubry JM. Lithium: updated human knowledge using an evidence based approach: Part I: 
Clinical efficacy in bipolar disorder. CNS Drugs 2009;23(3):225-40.

4. Grandjean EM, Aubry JM. Lithium: updated human knowledge using an evidence based approach. Part II: Clinical pharmacology and therapeutic monitoring. CNS Drugs.2009;23(4):331-49.

5. Greenblatt DJ. Basic pharmacokinetic principles and their application to psychotropic drugs. J Clin Psychiatry. 1993;54(Suppl. 9):8-13.

6. VanPutten T, Marder SR. Clinical use of neuroleptic plasma levels. In: Shriqui CL, Nasrallah HA, editors. Contemporary issues in the treatment of schizophrenia. Washington DC; American Psychiatric Press, 1995:435-55.

7. Severus WE, Kleindienst N, Seemuller F, Frangou $S$, Moller HJ, Greil W. What is the optimal serum lithium level in the long-term treatment of bipolar disorder - a review? Bipolar Disord. 2008;10:231-237.

8. Preskorn SH, Burke MJ, Fast GA. Therapeutic drug monitoring: principles and practice. PsychiatrClin North Am 1993;16:611-4.

9. Young RC, Biggs JT, Ziegler VE, Meyer DA. A rating scale for mania: reliability, validity and sensitivity. Brit J Psychiat. 1978;133:429-435.

10. Hamilton M. A rating scale for depression. J NeurolNeurosur Ps. 1960;23:56-62.

11. Jefferson JW, Greist JH. Lithium. In: Kaplan and Saddock's Comprehensive Text Book of Psychiatry. New Delhi: Wolters Kluwer (India) Pvt. Ltd; 2009.

12. Lamichhane N, Timasina RR, Thapa D K, Sharma R, Vaidya L, Subedi A et al. Serum Lithium in Patients in Remission of Bipolar Disorder. J Psychiatrists' Association of Nepal. 2019;8(2):26-29.

13. Tilak Ram Bhandari, Ashish Puri, Rani Walia, Shafiga Aslam, Moushumi P Mukherjee. Relationship between Dose, Serum Concentration and Response to Lithium Prophylaxis in Bipolar Disorders. Int J Pharm Sci Lett. 2014;4(2):399-402.

14. Panchal KM, Patel PP, Gandhi AM, Chauhan AP, Desai MK. A comparative study of two different brands of lithium carbonate in Patients of bipolar disorder. Int J Curr Res. 2018; 10(8):72519-24.

15. Diflorio A, Jones I. Is sex important? Gender differences in bipolar disorder. Int Rev Psychiatry. 2010;22(5):437-452.

16. Yassa R, Nair V, Nastase C, et al. Prevalence of bipolar disorder in a psychogeriatric population. I Affect Disord. 1988;14(3):197-201.

17. Eid L, Heim K, Doucette S, McCloskey S, Duffy A, Grof P. Bipolar disorder and socioeconomic status: what is the nature of this relationship? Int J Bipolar Disord. 2013;1:9.

18. Tsuchiya KJ, Byrne M, Mortensen PB. Risk factors in relation to an emergence of bipolar disorder: a systematic review. Bipolar Disord. 2003;5:231-42.

19. Merikangas KR, Herrell R, Swendsen J, Rossler W, Ajdacic-Gross V, Angst J. Specificity of bipolar spectrum conditions in the comorbidity of mood and substance use disorders: results from the Zurich cohort study. Arch Gen Psychiatry. 2008;65(1):47-52.

20. Eilers $R$. Therapeutic drug monitoring for the treatment of psychiatric disorders: clinical use and cost effectiveness. ClinPharmacokinet. 1995;29:44250.

21. Hopkins HS, Gelenberg, AJ. Serum lithium levels and the outcome of maintenance therapy of bipolar disorder. Bipolar Disord. 2000;2(3 Pt 1):174-179.

22. Sharma S, Joshi S, Chadda RK. Therapeutic drug monitoring of lithium in patients with bipolar affective disorder: experiences from a tertiary care hospital in India. Am J Ther. 2009;16(5):393-397.

23. Ratanajamit $C$, Soorapan $S$, Doang-ngern $T$, Waenwaisart W, Suwanchavalit L, Suwansiri S, et al. Appropriateness of therapeutic drug monitoring for lithium. J Med Assoc Thai. 2006;89(11):1954-60.

24. Marcus SC, Olfson M, Pincus HA, Zarin DA, Kupfer DJ. Therapeutic drug monitoring of mood stabilizers in Medicaid patients with bipolar disorder. Am J Psychiatry. 1999; 156(7):1014-8. 